\title{
O TRABALHO DO COORDENADOR PEDAGÓGICO E O PROJETO POLÍTICO PEDAGÓGICO: UMA RELAÇÃO NECESSÁRIA
}

\section{THE WORK OF THE PEDAGOGICAL COORDINATOR AND POLITICAL PEDAGOGICAL PROJECT: A NECESSARY RELATION SHIP}

\author{
Ana Paula Zaikievicz* \\ Marisa Schneckenberg ${ }^{* *}$
}

\begin{abstract}
RESUMO
O trabalho aqui apresentado é parte integrante de um estudo realizado em duas escolas municipais da cidade de Rebouças-PR. O propósito desse estudo foi observar como essas instituições definem o projeto político pedagógico e como esse documento vem sendo utilizado nas práticas de trabalho dos coordenadores pedagógicos. Diante disso, buscamos, também, analisar qual o trabalho que o coordenador pedagógico desenvolve nas instituições e qual a relação que esse profissional estabelece com o projeto político pedagógico da escola. Desse modo, nosso objetivo foi observar como se dá essa relação e quais os seus resultados para o desenvolvimento da escola e, consequentemente, para os alunos que ali estão inseridos.
\end{abstract}

Palavras-chave: Projeto político pedagógico. Coordenador pedagógico. Gestão escolar.

\begin{abstract}
This paper brings to a conclusion a study realized at two municipal schools at the municipality of Rebouças PR, which aimed to observe how both institutions define the pedagogic political project and how it has been applied by the pedagogical coordinators. Moreover, the acts developed by the pedagogical coordinators at these institutions and what is the relation established by this professional and the pedagogic political project of the school is also analyzed. Therefore, our aim was to observe this relation and what are the results to the school development and consequently, to its students.
\end{abstract}

Keywords: Pedagogic political project. Pedagogical coordinator. Schoolmanagement.

\footnotetext{
*Pedagoga, Especialista em Educação, Professora da Rede Municipal de Ensino de Ponta Grossa - PR. anapaulaz20@hotmail.com ** Pedagoga, Doutora em Educação, Professora do Departamento de Pedagogia/Unicentro/I. marisas@irati.unicentro.br
} 


\section{Introdução}

A pesquisa aqui apresentada tem como temática central estudar o trabalho do coordenador pedagógico e sua relação com o projeto político pedagógico da escola, a fim de verificar como se estabelece essa analogia na prática. Nesse sentido, buscamos dividi-la em três partes principais. No primeiro momento, apresentamos os materiais e os métodos, justificamos a importância da pesquisa e o modo como foi realizada.

No segundo momento, apresentamos alguns resultados obtidos com a realização deste estudo, e no terceiro e último momento realizamos algumas discussões sobre a temática. Fazemos, assim, um diálogo teórico entre os fundamentos da pesquisa e a coleta dos dados.

A problemática principal desta pesquisa é compreender o trabalho que o coordenador pedagógico desenvolve no contexto escolar e a relação que esse profissional estabelece com o projeto político pedagógico de sua escola. Buscamos, pois, analisar como o projeto político pedagógico vem sendo utilizado no espaço escolar e qual a importância que a escola lhe atribui. Propusemo-nos a pesquisar essa temática por acreditar que, ao haver uma integração entre o trabalho do coordenador pedagógico com o projeto político pedagógico, a escola alcançará uma melhor condição de desenvolvimento, tanto no processo de ensino e aprendizagem como no processo de relação com a comunidade escolar que convive dentro do espaço escolar no dia a dia.

Sendo a escola um local de formação de pessoas, as quais são preparadas para viver em sociedade como sujeitos atuantes, e não apenas como seres passivos, essa instituição precisa ser organizada e planejada para que se tenha um ano letivo comprometido com o ensino e com o desenvolvimento integral dos alunos.

Dessa forma, podemos compreender que a escola é um "[...] espaço social em que ocorrem movimentos de aproximação e de afastamento, onde se produzem e reelaboram conhecimentos, valores e significados" (ANDRÉ, 2003, p. 15). Sendo assim, a instituição escolar tem a necessidade de uma organização dentro de seu espaço, e é nesse sentido que se fazem necessários o trabalho do coordenador pedagógico e a definição do projeto político pedagógico.
Vale ainda lembrar que a escola é um local de formação de pessoas, por isso precisa ser um espaço de interação entre o conhecimento, a visão de mundo e de sujeito, e ainda estabelecer um compromisso com o trabalho que desenvolve.

Para que isso se efetive, é necessário que haja uma equipe preparada para auxiliar nessa organização, e um planejamento que venha estabelecer as bases de funcionamento da instituição. Assim, surge a necessidade do trabalho do coordenador pedagógico em consonância com o projeto político pedagógico, os quais devem estabelecer uma estreita relação, a fim de se realizar um trabalho coerente e eficaz na escola.

Considerando a importância da prática escolar para o desenvolvimento do nosso estudo, a coleta de dados da pesquisa desenvolveu-se em duas escolas municipais da cidade de Rebouças-PR, entre 2010 e 2011. No decorrer da pesquisa, realizamos entrevistas com profissionais das escolas e analisamos os projetos político pedagógicos de ambas.

A entrevista foi realizada com seis profissionais, e eles responderam, em média, cinco questões, as quais foram direcionadas para o coordenador pedagógico, para o gestor e, também, para um professor de cada instituição pesquisada. Esse instrumento foi escolhido porque nos concede uma maior veracidade das respostas, bem como uma maior interação entre o entrevistador e o entrevistado. Para Ludke (1986, p.35):

[...] O entrevistador precisa estar atento não apenas $[\ldots]$ ao roteiro preestabelecido em respostas verbais que vai obtendo ao longo da interação. Há toda uma gama de gestos, expressões, entonações, sinais não-verbais, hesitações, alterações de ritmo, enfim, toda uma comunicação não verbal cuja captação é muito importante para a compreensão e a avaliação do que foi efetivamente dito.

Nesse sentido, faz-se necessário que o pesquisador conheça o assunto e esteja focado no entrevistado, a fim de não perder pontos que podem ser cruciais para seu trabalho.

\section{Os determinantes do trabalho do coorde- nador pedagógico}

Ao refletirmos sobre a atuação do coordenador na contemporaneidade, percebemos que ele se 
constitui como peça angular na instituição escolar, pelo imenso trabalho que vem desempenhando. No entanto, muitas vezes a escola não compreende a verdadeira função desse profissional, fato esse que pode ser explicado pela complexa trajetória vivenciada por ele até chegar à atualidade.

Essa trajetória contribui para que, na atualidade, sua função seja confundida com as ações que realizava no passado, as quais estavam relacionadas ao trabalho do supervisor escolar e, mais tarde, à função do orientador educacional, que já apresentava características diferentes, porém, ainda, um tanto controladoras. Assim, Vasconcellos (2004) afirma que muitas das dificuldades que vêm ocorrendo no trabalho da coordenação pedagógica se fundamentam na configuração histórica da função, associada ao controle.

Em relação a essa ideia, temos como referência estudos de Grinspun (2001) que nos permitem perceber que, com o passar dos tempos e com as mudanças que vieram a ocorrer na sociedade, em especial na área educacional, os próprios orientadores educacionais - como eram chamados na época - foram transformando suas práticas educacionais, contribuindo assim para o surgimento da coordenação pedagógica.

Esta surgiu apresentando um novo viés e um novo método de trabalho junto à gestão escolar, deixando de realizar o atendimento diretamente com o aluno, bem como de atuar com os professores tendo como base o controle das práticas pedagógicas por eles desenvolvidas. Assim, o coordenador pedagógico passou a trabalhar especialmente com o professor, dando a este um atendimento especial em relação às suas dúvidas e dificuldades encontradas no cotidiano.

Na verdade, o coordenador faz parte da gestão escolar. Sendo assim, faz-se necessário que compreendamos que a equipe gestora se consolida como líder de todo o funcionamento institucional nos aspectos físicos, pedagógicos, burocráticos, de recursos humanos, entre outros. Pode-se afirmar, portanto, que os alunos não se desenvolvem apenas no espaço da sala de aula, mas, sim, no universo integral da escola. Daí a importância de a instituição escolar ser bem estruturada e bem organizada, para que o aluno tenha plenas condições de se desenvolver integralmente.
Sabe-se que toda escola, independentemente de seu porte, necessita de uma equipe pedagógica e/ou gestão escolar, que se constitui principalmente por um gestor e um coordenador pedagógico. Ambos devem desenvolver um trabalho em parceria, possibilitando à comunidade escolar um melhor ambiente de trabalho. Para Lück (1989, p.7):

O clima emocional de trabalho, o estabelecimento de prioridades de ação, o tipo de relacionamento professores-professores, professores-alunos, escola-comunidade, dentre outros aspectos importantes da vida escolar, dependem, sobremaneira, da atuação dos elementos que ocupam aquelas posições.

Os elementos a quem a autora se refere constituem a equipe gestora da escola, o que não justifica pensarmos ser essa equipe a única responsável por todos os acontecimentos que venham a ocorrer na instituição. Porém, essa equipe se caracteriza como a liderança; diante disso, precisa estar apta e ter plenas condições de desenvolver um bom trabalho. A gestão escolar precisa trabalhar em grupo, zelando pela democracia e pela liberdade de expressão de cada sujeito presente na escola, pois assim ela vem romper com a administração escolar, a qual se define como forma ou ação centralizadora e autoritária.

Tal fato contribuía para que esse profissional, o administrador escolar, fosse caracterizado como um sujeito autoritário, ainda mais porque tomava todas as decisões isoladas da comunidade escolar e não permitia que a mesma contribuísse na gestão da instituição. Isso ocorria porque a administração escolar possuía suas raízes na administração de empresas. Conforme Andriollo (2008, p. 15):

A administração escolar, durante décadas, seguiu de forma muito semelhante à da administração de empresas, o que não contribuiu muito para que a escola cumprisse com o seu papel e objetivos pedagógicos, nem atendesse às necessidades educacionais de sua clientela.

Nessa ótica, é visível observar que a escola não obtinha um bom desenvolvimento, pois se baseava num modelo de administração que tinha como objetivo o lucro. Desse modo, verificamos que há uma enorme diferença entre uma escola e uma empresa, visto que a primeira obtinha o lucro e o sucesso, já a segunda objetivava o ensino e a formação dos alunos. 
Já a gestão escolar que objetivamos, atualmente, nas escolas, é marcada pela democracia, e o gestor ocupa o papel do então diretor ${ }^{1}$. Este agora desenvolve seu trabalho juntamente com o coletivo, permitindo a participação da comunidade escolar nas decisões a serem tomadas. Busca uma escola autônoma, dividindo tarefas a fim de construir na instituição escolar um espaço coletivo, em que todos colaboram.

Tais ações direcionam-se para a implementação da gestão democrática, visto que esta se estabelece por meio da participação e da presença da comunidade na vida escolar através de mecanismos significativos de representatividade e de participação política, fundamentados na transparência das decisões e na real possibilidade de interferência no processo de tomada de decisões.

Depreende-se disso que a gestão democrática é uma das principais características da gestão escolar, por permitir que toda a comunidade escolar colabore no ato de gerir a escola e esta venha estabelecer um vínculo mais próximo com a sociedade.

Vale ressaltar ainda que a gestão escolar democrática é prevista pela Lei de Diretrizes e Bases da Educação Nacional, Lei 9394/96, a qual afirma, no inciso VII do artigo $3^{\circ}$, que é dever da escola possuir uma "gestão democrática do ensino público, na forma desta lei e da legislação dos sistemas de ensino" (BRASIL, 2007, p. 14). Evidencia-se, assim, a importância de as escolas implementarem tal proposta, a qual traz em seus princípios a liberdade, a autonomia e, principalmente, a possibilidade de participação coletiva. Já o coordenador pedagógico torna-se parceiro na conquista de práticas participativas. Segundo Pimenta (1991, p.36), o coordenador pedagógico é igualmente responsável, “buscando uma escola cada vez mais autônoma e humanizadora. Para isso, dará cada vez mais apoio ao currículo, estando sempre presente a todas as atividades e sendo desencadeador de um processo voltado para 'a melhoria do processo educativo [...]"'.

Percebemos, portanto, quão necessária é a presença do coordenador pedagógico na escola, sendo que sua função é estabelecer um elo entre

\footnotetext{
${ }^{1}$ Segundo Vasconcellos $(2004$, p. 60), “[...] o diretor costuma corresponder ao arquétipo do poder, que tradicionalmente está vinculado a práticas autoritárias, que variam num espectro que vai do capricho ou implicância à atitudes despóticas e até de violação de direitos humanos fundamentais".
}

professores-professores, professores-alunos, escola-comunidade, contribuindo no desenvolvimento da instituição escolar, possibilitando ao aluno um melhor lugar para aprender, bem como uma estreita relação da escola com a comunidade em que está inserida. Durante nossa coleta de dados, realizamos uma questão referente ao trabalho que o coordenador desenvolve nas duas escolas. A gestora da Escola $\mathrm{A}^{2}$ foi a primeira entrevistada; ela nos relatou que

\section{[...] o coordenador [...] é a base [...], é ele que vai direcionar todo o trabalho [...] ele vai auxiliar os professores, ele vai procurar o trabalho, vai pro- curar livros, [...] é a base.}

Percebemos que o coordenador pedagógico é visto como um profissional de apoio ao corpo docente. Ele tem a incumbência de colaborar no trabalho dos professores, auxiliando-os na busca de materiais, sendo a base de todo o trabalho desenvolvido na escola. Entretanto, não foi mencionado, durante a entrevista, como ocorre esse atendimento ao corpo docente, se é por meio de reuniões, da hora atividade, ou por um diálogo entre coordenador e professor.

Concordamos plenamente com a gestora, quando ela cita que o coordenador direciona o trabalho dos professores, fornecendo-lhes materiais, quando estes encontram dificuldades em suas práticas pedagógicas. No entanto, acreditamos que esse trabalho precisa acontecer por meio de uma relação horizontal entre ambos, havendo um desejo de mudança e de transformação da prática do professor.

Ao questionar as coordenadoras sobre o trabalho que desenvolvem na escola, foi possível observar que a coordenadora da Escola A assumiu essa função recentemente, como nos mostra em sua fala:

É o meu primeiro ano que atuo como coordenadora, eu não tenho uma prática de trabalho, mas eu acredito que o papel do coordenador é [...] auxiliar os professores, orientar e também verificar se realmente o que foi proposto, o que foi pedido no projeto esta sendo trabalhado e seguido. (COORDENADORAA).

Já em relação à coordenadora da Escola $\mathrm{B}$, foi possível perceber uma considerável diferença entre ela e a coordenadora anterior. Ao dar sua resposta

\footnotetext{
${ }^{2}$ As escolas participantes são descritas como Escola A e Escola B na intenção de proteger a identidade dos sujeitos envolvidos na pesquisa.
} 
sobre o trabalho que desenvolve, pôde-se constatar que ela gosta do que faz, porém está sobrecarregada de tarefas.

[...] a nossa escola ano passado tinha duas coordenadoras aqui junto, então esse ano esta bem difícil [...] porque você não consegue sentar e programar alguma coisa, você fica correndo de um lado pra outro [...] e então tem pouco tempo para desenvolver um bom trabalho com os professores em sala de aula e tal, então é uma correria. (COORDENADORA B).

A referida coordenadora ainda complementa, em sua resposta, que as questões burocráticas da escola, bem como as atividades corriqueiras, dificultam seu trabalho, que poderia ser dedicado a auxílio pedagógico aos professores e aos alunos, que são o foco principal da escola: "[...] acabo deixando de lado a ajuda que seria mais importante paro o aluno [...] e acabo socorrendo [...] problema [...] de dia a dia que você não tem como fazer".

Segundo o depoimento da coordenadora B, sabemos que o desvio de funções, por parte do coordenador, é uma triste realidade no contexto educacional. Esse profissional desenvolve inúmeras tarefas diárias que nem sempre são de sua incumbência. Como nos mostra Clementi (2010, p. 62, grifo do autor), "muitos coordenadores falam sobre o excesso de atividades que lhe são atribuídas, motivo pelo qual convivem com o stress e a correria constante".

De acordo, ainda, com a coordenadora $\mathrm{B}$, o trabalho do coordenador é desvalorizado por parte do corpo docente, por professores que não conhecem a função do coordenador e, por isso, lhe atribuem tarefas que nem sempre são de sua responsabilidade. Nesse sentido, a Coordenadora B pontua:

[...] é, eu acho que todo professor devia estar na coordenação, passar uma vez pela coordenação para sentir como que é isso aqui, porque quem olha de fora acha que aqui é bom de ficar $e$ na verdade não é, tem horas assim que você acha que vai enlouquecer, são várias pessoas te procurando.

As queixas da coordenadora revelam certa desvalorização e desmotivação dentro de seu ambiente de trabalho. Em relação a essa questão, Clementi (2010) enfatiza que os desejos de atuação do coordenador nem sempre condizem com a realidade encontrada no cotidiano da escola. Diante disso, esse profissional passa a desenvolver uma guerra diária que geralmente resulta em stress e frustração.

De acordo com as respostas fornecidas pelas coordenadoras, podemos perceber que ambas têm como prioridade em seus trabalhos o apoio ao corpo docente, entretanto nem sempre conseguem realizar essa ação, devido à diversidade de tarefas que desenvolvem diariamente.

Neste sentido, consideramos ser fundamental que o coordenador pedagógico seja

[...] visto como alguém com capacidade de apoio, que impulsione o grupo com o qual trabalha, através de um posicionamento mais crítico em relação à realidade escolar e global. É a percepção da realidade que permite a este profissional exercer uma função social e politicamente mais ampla, estimulando os professores a uma compreensão mais contextualizada e consciente das ações realizadas. (FILIPKOWSKI, 2005, p. 98).

Cabe destacar, também, uma outra função do coordenador, a qual remete à liderança na formulação e implementação do projeto político pedagógico, sendo esse o documento que vai direcionar todas as ações da escola durante o ano letivo. Todavia, para que isso se concretize são necessárias ações que impulsionem esse trabalho e primem pelo envolvimento de todos. Ou seja:

[...] esta elaboração conjunta permite que o $\mathrm{PCP}^{3}$ ouça os anseios de seus pares em busca de melhores caminhos, auxiliando no processo de estabelecimento, metas e objetivos a serem alcançados por todos, oportunizando uma relação de corresponsabilidade por parte dos professores, tanto para os acertos quanto para as dificuldades ou falhas que possam advir. (MIZIEIRA, 2004, p.2).

\section{O projeto político pedagógico enquanto ob- jeto de trabalho do coordenador pedagógico}

Para melhor compreendermos o PPP, faz-se necessário apresentarmos o conceito de projeto. Segundo Duny (2005, p. 13), a palavra projeto advém de "projetar, 'jogar para frente'; vem do latim projicere, cujo particípio deu origem a projectum, origem do termo. O projeto valoriza a realização de

3 Professor Coordenador Pedagógico - nomenclatura utilizada pela Secretaria de Estado da Educação do Paraná - SEED-PR. 
um desejo, de um sonho, de um objetivo". Agora, ao trazermos a palavra projeto para o âmbito educacional, a mesma toma uma maior proporção, visto que projetar torna-se o primeiro passo para a escola se consolidar como espaço de democratização, de saber, de autonomia, de liberdade, de participação e de conhecimento perante a sociedade.

Já ao falarmos em projeto político pedagógico, juntamos três vertentes, sendo que o projeto se concebe como estabelecimento de metas; a palavra político significa, nesse contexto, o direito de todos participarem; e, finalmente, o adjetivo pedagógico refere-se a ações inerentes ao processo de ensino e aprendizagem.

Conforme Vasconcellos (2004, p.17), o projeto político pedagógico também se define como:

[...] plano global da instituição. Pode ser entendido como a sistematização, nunca definitiva, de um processo de planejamento participativo, que se aperfeiçoa e se objetiva na caminhada, que define claramente o tipo de ação educativa que se quer realizar, a partir de um posicionamento quanto à sua intencionalidade e de uma leitura da realidade. Trata-se de um importante caminho para a construção da identidade da instituição. É um instrumento teórico-metodológico para a transformação da realidade. Enquanto processo, implica a expressão das opções da instituição, de conhecimento e julgamento da realidade, bem como das propostas de ação para concretizar o que se propõe a partir do que vem sendo; e vai além: supõe a colocação em prática daquilo que foi projetado, acompanhado da análise dos resultados.

Justifica-se, assim, a importância de a escola possuir seu projeto político pedagógico, o qual não pode constituir-se apenas como um documento de ordem burocrática que a escola deve ter, mas como um documento que traz em seu núcleo a maneira como a escola trabalha, a visão de mundo e de sociedade apresentada por essa instituição, o tipo de cidadão que ela almeja formar.

A fim de perceber a importância do PPP para as escolas, questionamos os profissionais sobre a definição desse projeto e sobre como ele vem sendo utilizado nas instituições escolares. A gestora da escola A nos respondeu que

[...] o projeto político pedagógico é muito importante, ele direciona todo o trabalho da escola, é a base de tudo, onde os professores vão fazer, vão ter livre acesso [...] principalmente na hora atividade é ele que comanda, direciona todo o trabalho da escola. (GESTORA A, ESCOLAA).

Já a gestora da escola B afirmou que, para ela, o projeto político pedagógico

[...] conduz, nos orienta para que possamos ter uma linha de trabalho e para que esse trabalho seja unificado no sentido de que todos caminhem na mesma direção para atingir o mesmo fim, o mesmo objetivo. Se não tivermos uma linha de trabalho a gente se dispersa e não chega a lugar nenhum. (GESTORA B, ESCOLA B).

Comparando as duas respostas, podemos perceber que ambas concebem o projeto político pedagógico como o documento norteador do trabalho da escola, sendo esse o documento em que a escola precisa se apoiar para desenvolver um trabalho significativo. Portanto, na resposta da gestora B podemos observar que a escola precisa caminhar unida, seguindo um mesmo objetivo, e que o PPP é o documento que direciona essa caminhada, fato esse que não foi citado na resposta da gestora $\mathrm{A}$.

Ao questionarmos as coordenadoras pedagógicas sobre a mesma pergunta, elas nos forneceram as seguintes respostas:

[...] o projeto político pedagógico é o documento que norteia todo o trabalho do professor, é a base de tudo, é ali que você vai colocar os anseios da escola, o que ela precisa, o que ela não precisa, por isso há necessidade de você estar praticamente reformulando esse projeto, vendo se dá certo ou não, se é uma base, um apoio que o professor tem para direcionar o trabalho [...]. (COORDENADORA A, ESCOLAA).

Já para a coordenadora da escola B,

[...] o projeto político pedagógico objetiva entender o desenvolvimento total da escola [...], que abrange desde a parte pedagógica, a parte de funcionamento da escola, a parte de administração, funcionários [...] ele é muito importante no sentido de que você pode analisar [...] aquilo que a gente está oferecendo aos nossos alunos. É o documento que mostra [...] a escola num todo [...] eu acho que é feito uma análise da escola como se fosse mesmo a identidade da escola. 
Diante de tais falas podemos observar que as duas coordenadoras possuem uma visão muito clara do PPP, tendo em vista que cada uma pontuou pontos importantes sobre o documento. A coordenadora A abordou a necessidade da revisão do PPP, que é fator de extrema importância para a implementação do documento.

Já a coordenadora B abordou a questão do PPP permitindo que se faça uma análise da escola como um todo, possibilitando observar o que a mesma vem oferecendo aos alunos. A questão relatada pela coordenadora nos mostra a sua preocupação com o desenvolvimento dos alunos, bem como os ensinamentos que a escola vem proporcionando a eles.

Como as escolas consideram o PPP um instrumento norteador de seus trabalhos, buscamos, também, verificar por quem e como esse projeto vem sendo formulado nas instituições pesquisadas. $\mathrm{Na}$ escola A, tanto a gestora como a professora nos deram praticamente a mesma resposta, como podemos observar a seguir.

Bom, ele é formulado principalmente pelos professores, pais de alunos, $A P M F^{4}$, os funcionários [...] então é uma equipe dessa escola que formula o projeto político pedagógico e ele é construído coletivamente [...] e também tem a participação dos alunos. (GESTORA A, ESCOLAA).

Vejamos agora a resposta proferida pela professora A, da Escola A: "Sempre que possível [...] são reunidos professores, funcionários, pais, APMF, representante de alunos e ele é construído coletivamente". Prosseguimos a pergunta, questionando se ela já havia participado da formulação do PPP, então a professora respondeu: "Já, toda vez que ele é formulado todos os professores devem participar". (PROFESSORA A, ESCOLA A).

Já na escola $\mathrm{B}$, a coordenadora nos relatou que o projeto político pedagógico "é organizado pela coordenação, é formulado por todos os professores, funcionários, APMF e sempre um representante de cada setor da escola". (COORDENADORA B, ESCOLA B).

Nessa resposta, a profissional afirma que o PPP é organizado pelo coordenador pedagógico. Outro fator que merece destaque em sua fala remete

\footnotetext{
${ }^{4}$ Associação de Pais, Mestres e Funcionários da escola.
}

à participação de todo o corpo docente na elaboração do PPP. A referida professora informa que cada professor possui uma realidade, e esta precisa ser considerada.

Também realizamos a pergunta para a gestora dessa escola, a qual nos relatou que o PPP é construído a partir de várias etapas, ou seja:

Tem as etapas de organização onde organizamos grupos por série, ouvimos, discutimos e relatamos. É claro que para fazer isso em horário de escola tem que usar hora atividade, ou vamos dizer assim num dia chuvoso poucos alunos vêm, ai é a oportunidade que temos. Às vezes a própria secretaria suspende as aulas para que a escola possa concluir conjuntamente [...]. ( GESTORA B, ESCOLA B).

Reelaboramos a questão e questionamos se para ela é importante que o PPP seja formulado coletivamente e fique à disposição de toda a comunidade escolar, durante o ano letivo. Então, a profissional respondeu: "Juntos planejamos pra que não seja desviado o objetivo da escola" (GESTORA B, ESCOLA B). Aqui, mais uma vez, a gestora reforçou a questão de a escola ter muito claro seu objetivo, para que não haja um desvio de percurso durante o ano letivo.

Tendo em vista que o PPP não é um documento que apresenta apenas as características de cada escola, e sim um documento que deve apresentar também as concepções de educação, de filosofia e de sociedade agregadas pela escola, formulamos uma pergunta sobre a fundamentação teórica do PPP. Na escola A obtivemos basicamente as mesmas respostas, tanto da gestora como da coordenadora e da professora: "A proposta foi formulada na LDB, nos PCNs, no Currículo Básico Nacional e também em outros autores que [...] a gente foi pesquisando e foi colocando". (GESTORA A, ESCOLA A). Também foram mencionados pela professora A os autores Lev Vygostski e Jean Piaget.

Já na escola B, tanto a gestora como a professora e a coordenadora mencionaram apenas os autores Jean Piaget e Lev Vygostski. Com o intuito de verificar se os PPPs dessas escolas apresentam, em seu texto, as teorias dos autores citados, bem como a concepção que as escolas assumem sobre educação, filosofia e sociedade, realizamos uma análise desses projetos. 
Nessa análise, podem ser consideradas algumas incoerências entre o documento e as respostas dadas pelas profissionais. Vejamos no PPP da escola A:

O PPP da Escola [...] baseia-se nos princípios éticos da autonomia, da responsabilidade, da solidariedade e do respeito ao bem comum, nos princípios políticos dos direitos e deveres de cidadania, do exercício à criticidade e do respeito à ordem democrática. (PROJETO POLITICO PEDAGOGICO, ESCOLA A, 2009, p.11).

Apesar de o parágrafo apresentar conceitos viáveis sobre a educação e os princípios da escola, não nos ficam claras as concepções de filosofia e de sociedade que a escola possui. De acordo com Veiga (1998, p.13), "a discussão do projeto político-pedagógico exige uma reflexão acerca da concepção da educação e sua relação com a sociedade e a escola, o que não dispensa uma reflexão sobre o homem a ser formado, a cidadania e a consciência crítica".

Tendo em vista o projeto político pedagógico da escola $\mathrm{B}$, destacamos o seguinte parágrafo:

A escola [...] tem como linha norteadora do processo pedagógico o construtivismo com base tradicional. Embasada em alguns pensadores, o que se almeja não é simplesmente o repasse de conteúdos visando quantidade, ao contrário, busca-se criar condições favoráveis que facilitem o aprendizado de maneira prazerosa e não imposta, o professor nesse cenário aparece como mediador dessa situação, buscando despertar no aluno a curiosidade, a criatividade, como forma de construção do conhecimento sistemático, visando a formação do educando num todo harmonioso preparando-o para a vida, objetivando-o a exercer seu papel na sociedade como cidadão consciente e democrático. (2009, p.14).

Nesse parágrafo está contemplado o ensino tradicional, que não está ligado nem a Vygostski nem a Piaget. Quanto à teoria de Vygotski, fez-se a seguinte declaração:

Menciona-se aqui Vygotsky, como pressuposto para a prática educativa. Em seus escritos relata que a apropriação se dá como uma interiorização da experiência sociocultural dos adultos e do meio que cerca a criança, ele propôs que sempre é necessária uma mediação, a experiência coletiva para que possa existir experiência individual. (2009, p.22).
Notamos incompatibilidade entre a menção de Vygotsky como pressuposto para a prática educativa - a qual, segundo a citação apresentada, implicaria uma mediação entre aluno e professor para o desenvolvimento do processo de ensino e aprendizagem - e o que foi exposto no parágrafo que diz que a "escola tem como linha norteadora do processo pedagógico o construtivismo com base no tradicional". Isso porque que nem o construtivismo visa à mediação entre o professor e o aluno, nem o ensino tradicional, o qual ocorre por meio do poder do professor, que não estabelece mediação com o aluno, pois é dotado de todo o conhecimento, e o aluno está na escola para aprender.

A esse contexto podemos acrescentar Veiga (1998, p.61), que afirma:

O projeto político pedagógico configura-se como um instrumento de trabalho que mostra o que vai ser feito, quando, de que maneira e por quem, para chegar aos resultados desejados. Deve, para tanto, explicitar uma filosofia e harmonizar autonomia definindo-lhe o compromisso com a clientela.

Percebemos, nessa ótica, a importância de o projeto político pedagógico apresentar em seu núcleo o viés em que a escola acredita, a fim de se compreender o caminho que essa instituição irá percorrer durante o ano letivo.

Vale ainda lembrarmos que o projeto político pedagógico é um documento obrigatório nas escolas, pois está contemplado na Lei de Diretrizes e Bases da Educação - LDB Lei 9394/96, em seu artigo 12: "Os estabelecimentos de ensino, respeitadas as normas comuns e as do seu sistema de ensino, terão a incumbência de: I - elaborar e executar sua proposta pedagógica" (BRASIL, 2007, p.18).

A escola precisa ter consciência da necessidade desse documento para o desenvolvimento de um melhor trabalho educativo, e não formulá-lo apenas por imposição dos órgãos superiores educacionais, como afirmam Diógenes e Carneiro (2005, p.11):

[...] o Projeto Político Pedagógico não pode ser encarado, apenas, como modismo ou exigência das instâncias centrais de decisão, mas acima de tudo, como tomada de consciência por parte da escola, diante da sua missão e função social no atual contexto histórico em que vivemos. 
Ao falarmos sobre a formulação do PPP, sabemos que o coordenador pedagógico é peça fundamental nesse processo, mas ele não pode assumir essa tarefa sozinho. O que deve acontecer é o envolvimento e a participação de toda a comunidade escolar: professores, alunos, pais, comunidade, órgãos colegiados $^{5}$, gestores, funcionários e quem mais quiser participar.

Sobre esse aspecto da participação, buscamos também verificar como ocorre a revisão do PPP. Na escola B, segundo as respostas fornecidas pela gestora, essa revisão ocorre sempre que for necessário verificar algum resultado de trabalho realizado pela escola. Ou, então, quando um professor sente alguma dificuldade em seu trabalho, como podemos observar na fala de uma gestora: "Quando a gente vai rever aquele resultado, seja ele positivo ou negativo, $[. .$.$] a gente diz então vamos retomar a proposta$ pedagógica, vamos pegar e vamos ver o que é que temos que refazer". (GESTORA B, ESCOLA B).

É possível perceber que a gestora $B$, da escola $\mathrm{B}$, é bastante preocupada com o trabalho que a escola desenvolve, visto que ela sempre cita em suas falas a importância de gestores e professores caminharem juntos para que ninguém se desvincule dos objetivos estipulados, visando sempre à aprendizagem dos alunos. Quanto à participação no PPP, afirma Vasconcellos (2004, p.17):

O Projeto Político Pedagógico é o plano global da instituição. Pode ser entendido como a sistematização, nunca definitiva, de um processo de planejamento participativo, que se aperfeiçoa e se objetiva na caminhada, que define claramente o tipo de ação educativa que se quer realizar, a partir de um posicionamento quanto à sua intencionalidade e de uma leitura da realidade.

Ao abordar essa questão da revisão do PPP para a professora da escola $B$, obteve-se a seguinte resposta:

Sempre no começo do ano nas semanas pedagógicas e às vezes na metade do ano, também na semana pedagógica de julho, é sempre dado mais uma lida pra ver o que precisa reformular, pois todo ano muda a clientela, os alunos [...] (PROFESSORA B, ESCOLA B).

\footnotetext{
${ }^{5}$ Grêmio estudantil, Conselho Escolar, Associação de Pais, Mestres e Funcionários (APMF).
}

Nota-se, nessa resposta, um aspecto de suma importância: a consciência da professora em considerar que todo ano mudam-se os alunos e, consequentemente, as características dos mesmos.

Quando the apresentamos essa questão, a coordenadora da escola nos falou sobre a nova reformulação que iria acontecer, a qual estava sendo organizada pela Secretaria Municipal de Educação. Diante disso, podemos ressaltar alguns pontos centrais de sua fala:

\section{[...] a gente vai fazer essa revisão com a ajuda da Secretaria que está coordenando essa revisão, ai a gente não tem uma ideia de como vai ser, já vai contar com a participação dos professores de cada série que já vão participar dos encontros [...]. Pelo menos pelo que eles estão pensando é para a gente analisar a nova proposta porque o município já está com um outro planejamento e a gente sabe que não é fácil, os professores levam tempo para se adaptar. Então jogar [...] numa se- mana o que vai fazer durante o ano não é fácil, eu acho que vai ter que ser feito um trabalho bem feito mesmo, para que a gente tenha resultado. (COORDENADORA B, ESCOLA B).}

Podemos perceber que a coordenadora considera viável a nova formulação que está sendo organizada pela Secretaria Municipal de Educação; para tanto, ela acredita que os professores precisam de tempo para se adaptar à nova proposta que vem sendo implantada no município, pois, se não for bem trabalhada, não sairá do papel.

Sobre a questão da nova formulação do PPP, a coordenadora da escola A também nos expõe seu ponto de vista:

É interessante, tem seus prós e contras no sentido de que o professor vê que há um representante só por série; eu acredito que deveriam ser todos, não só um representante, principalmente dos professores. Eu acredito que todos deveriam participar, porque representar é difícil [...] eu tenho um pensamento e o outro professor pensa diferente.

Essa reformulação do PPP, que está sendo organizada pela Secretaria Municipal de Educação em parceria com a assessoria pedagógica externa, ainda está no início do processo, mas os profissionais pesquisados não sabem muito bem como ela irá ocorrer. Diante disso, não podemos nos posicionar frente a essa situação, pois também não sabemos, de fato, como ocorrerá tal implementação. 
Vale ainda lembrar a importância de o PPP ser construído coletivamente, levando-se em conta a realidade de cada instituição e da comunidade escolar nela presente, pois só assim o documento se tornará um instrumento de trabalho para os usuários e oportunizará a conquista da autonomia e da gestão democrática às escolas, fatores de suma importância para o desenvolvimento das mesmas.

Para finalizar a entrevista, formulamos uma questão central, a qual objetivou compreender como vem ocorrendo a participação do coordenador pedagógico na realização e implantação do projeto político pedagógico.

A professora da Escola A relatou que

[...] iniciou esse ano na escola, mas que sempre teve livre acesso ao PPP. Ela, a coordenadora, estava à disposição para qualquer momento que o professor necessitasse [...]. (PROFESSORA A, ESCOLAA).

Como a professora entrevistada não mencionou o trabalho do coordenador na formulação e implantação do PPP, estendemos a pergunta, questionando se o coordenador se envolve no projeto político pedagógico da escola. No entanto, a professora apenas respondeu "Sim, com certeza" (PROFESSORA A, ESCOLA A).

Também fizemos essa pergunta para a coordenadora, e ela nos deu a seguinte resposta:

Acredito que o papel do coordenador é verificar se o professor está ciente de tudo que contém nele e auxiliá-los e orientá-los na condução da proposta. (COORDENADORA A, ESCOLAA).

Como essa profissional nos havia informado que seu início na função de coordenadora acontecera recentemente, e que, por esse motivo, não possuía, ainda, uma prática de trabalho, perguntamos se ela pretende utilizar o PPP como ferramenta para desenvolver a sua ação pedagógica. Sua resposta foi esta:

Sem dúvida, porque uma vez que ele foi elaborado, que teve um trabalho e toda uma colaboração, se é um documento ele não pode ser engavetado e ele não pode ser feito meramente por fazer e deixar lá e ninguém ter conhecimento. (COORDENA-DORA A, ESCOLAA).
Em decorrência da resposta apresentada pela coordenadora, depreende-se que a mesma tem consciência da dimensão do PPP, vendo-o como instrumento de seu trabalho. Ela destaca também que esse documento não deve ser construído para ficar engavetado.

Podemos dizer que as respostas fornecidas pelas profissionais nos mostraram como elas consideram importante o coordenador desenvolver o seu trabalho mediado pelo PPP. Entretanto, não nos relataram de que forma ocorre essa mediação.

Tendo em vista a importância de o PPP ser formulado dentro do coletivo, Veiga (1998, p. 14) considera que

[...] o processo de construção do projeto é dinâmico e exige esforço coletivo e comprometimento; não se resume, portanto, à elaboração de um documento escrito por um grupo de pessoas para que se cumpra uma formalidade. É concebido solidariamente com possibilidade de sustentação e legitimação.

Podemos entender que o processo de construção de um PPP não se resume apenas em seguir uma normatização, é preciso que haja um comprometimento da comunidade escolar, a qual precisa compreender esse documento como uma forma de a escola ampliar-se como instituição, tendo um apoio e um direcionamento para realizar suas ações.

Aplicamos a mesma questão para as profissionais da escola B. A primeira entrevistada foi a professora B, para quem a participação da coordenadora no processo de ensino e aprendizagem "é bem extensa, ela é bem colaboradora com os professores, ela vai atrás, ela procura, se você tem dúvida ela ajuda”. (PROFESSORA B, ESCOLA B).

Ainda questionamos como ocorre a participação da coordenadora durante o processo de formulação do PPP: "Presente, muito presente tanto na formulação dos projetos, dos planejamentos, em tudo ela está presente". (PROFESSORA B, ESCOLA B).

À gestora, perguntamos quem é responsável pela implementação do PPP na escola: "A coordenadora pedagógica com a diretora". (GESTORA B, ESCOLA B). Então a indagamos sobre a participação da coordenadora nesse processo: "Normalmente nós ganhamos da Secretaria de Educação um espaço pra discussão, e ela [a coordenadora] orienta a discussão, o debate e o estudo de conteúdos. Ela prepara 
com antecedência todo o material e lidera este processo". (GESTORA B, ESCOLA B).

Observa-se que, nas ações realizadas pela escola, a coordenadora da escola B é bem participativa e atuante. Certamente, ela possui uma visão clara de seu trabalho como integrante da equipe gestora. $\mathrm{Na}$ fala da gestora verificou-se, também, que a coordenadora gerencia as reuniões nas quais são discutidas as questões vigentes do projeto político pedagógico da escola. No que diz respeito às reuniões realizadas na escola, destacamos o que afirma Orsolon (2010, p.28):

O primeiro passo nessa direção é reunir os professores, o que não é tarefa fácil, pois trata-se de conciliar horários possíveis a todos. [...] É muito importante os professores perceberem que nesse horário o coordenador está totalmente envolvido com o grupo, pois essa atitude deverá favorecer o próprio envolvimento dos professores.

Como menção a essa ideia, entendemos que, quando o coordenador assume seu compromisso de líder das reuniões, isso gera maior envolvimento dos professores, os quais sentem que a coordenação está envolvida no trabalho e, consequentemente, também se envolvem mais. Nota-se, assim, a importância de o coordenador entender sua função e trabalhar objetivando a formação do coletivo, concretizando uma gestão democrática em que todos possam contribuir no ato de gerir e transformar a escola em um lugar acolhedor e benéfico a todos.

Finalmente, investigamos como a coordenadora da escola B concebe a sua participação na elaboração e revisão do PPP.

Então sempre que a gente faz reunião, como agora a gente estava fazendo uma reuniãozinha que está relacionada ao projeto político pedagógico [...], a gente sempre procura antecipar aos professores aquilo que vai fazer [...] procura que eles também participem na elaboração do projeto com ideias novas [...] mas nem todos participam como a gente gostaria. Aos poucos você vai vendo que as coisas vão mudando mais, é um processo longo, cada professor tem a sua maneira de trabalhar. Assim você conhece o professor que você tem [...] eles procuram me ajudar nesse sentido. A gente sempre procura ideias [...] para, na hora do recreio principalmente [...] envolvê-los um pouquinho mais (COORDENADORA B, ESCOLA B).
A fala da coordenadora vem ao encontro das falas apresentadas anteriormente pela gestora e pela professora, comprovando que, de fato, a coordenadora procura estabelecer uma boa relação com o corpo docente da escola, motivando-os a participar mais intensamente do PPP. No entanto, outro fator vem à tona novamente, o qual remete à falta de motivação de alguns professores, que nem sempre veem a necessidade de estar participando da gestão do PPP. Diante disso, é necessário que o coordenador e o gestor reflitam e busquem compreender os fatores que vem contribuindo para tal situação, a fim de desenvolverem mecanismos que revertam esse quadro.

Quanto à constatação de resistência, Orsolon (2010, p.22) diz que:

[...] o coordenador, como um dos articuladores desse trabalho coletivo, precisa ser capaz de ler, observar e congregar as necessidades dos que atuam na escola; e, nesse contexto, introduzir inovações, para que todos se comprometam com o proposto. À medida que essas novas ideias, além de conter algo novo, forem construídas, discutidas e implementadas pelos professores e coordenadores envolvidos, tornar-se-ão possíveis a adesão e o compromisso do grupo e, dessa forma, se reduzirão as prováveis resistências.

Orsolon nos mostra que o coordenador precisa observar as necessidades dos professores e trabalhar com base nas mesmas, pois a partir do momento em que a coordenação entender os anseios dos professores e fornecer-lhes apoio e confiança, estes se sentirão seguros em participar das ações propostas pelo coordenador. Desse modo, a escola ganhará mais força para introduzir em seu núcleo a transformação e o processo de melhoria constante.

Tendo obtidas as respostas das profissionais sobre essa problemática, realizamos uma análise nos PPPs das duas escolas, com o intuito de verificar se em seus textos está registrada a função do coordenador no processo de formação do projeto político pedagógico.

A escola deve ser autônoma e, quando falamos em autonomia, estamos falando ou defendendo que a comunidade escolar tenha um grau de dependência e liberdade para coletivamente pensar e discutir, planejar, construir e executar seu PPP, entendendo que neste está contido o projeto de educação ou de 
escola que a comunidade almeja, bem como estabelecer os processos de participação no dia a dia escolar. (PROJETO POLÍTICO PEDAGÓGICO, ESCOLA A, p. 189).

Sendo a autonomia um dos benefícios que a efetivação do projeto político pedagógico vem oferecer, faz-se necessário entendermos seu significado, qual seja: [...] oferece ao sujeito oportunidade de participar do processo de tomada de decisão. Trata-se da condição do sujeito de escolher o modo de agir ou resolver determinado problema junto a seus pares. Assim, a autonomia vem se destacando no contexto educacional como medida de alocação e distribuição de recursos, reforçando o sentido de gestão no desempenho de suas diversas funções, aumentando a participação local no governo da escola e, ainda, no desenvolvimento de procedimentos de avaliação externa.

É dessa forma que o PPP vem consolidar o processo, visto que ele permite a participação de todos e ainda apresenta, em suas páginas, o direito de a escola conquistar autonomia por meio de sua concretização e do seu conhecimento, oferecendo a todos a oportunidade de gerir a escola.

\section{Considerações finais}

Pode-se, com a realização desta pesquisa, pontuar ações do coordenador pedagógico para o desenvolvimento integral da escola. No entanto, a trajetória complexa marcada pelas muitas mudanças pelas quais esse profissional passou, contribuiu para que, hoje, ele seja visto muitas vezes de forma errônea pela comunidade escolar, a qual acaba confundindo-o com um profissional ainda autoritário e fiscalizador.

Tais fatos vêm também colaborar para que esse profissional tenha dificuldades em desenvolver o seu trabalho, pois precisa realizar muitas atividades que nem sempre seriam de sua responsabilidade, diminuindo, assim, o tempo que teria para trabalhar com a formação em serviço dos professores e com o projeto político pedagógico, que são hoje suas principais funções.

Acreditamos ser necessário haver uma melhor compreensão por parte da comunidade escolar sobre o trabalho que cabe ao coordenador pedagógico, a fim de que esse profissional possa contribuir, cada vez mais, com uma instituição em constante desenvolvimento.

Outra questão que merece destaque, nestas considerações, refere-se ao projeto político pedagógico. A realização do presente estudo possibilitou-nos entender a grandeza desse documento, tendo em vista os inúmeros benefícios que ele pode oferecer à escola.

Foi possível perceber, nas instituições pesquisadas, que ambas têm total clareza sobre a importância do PPP para o funcionamento de suas escolas, fato esse que consideramos como ponto positivo em ambas as instituições. Contudo, ainda existe certa resistência de alguns profissionais em trabalharem de acordo com o documento, desde a sua implantação até a sua implementação e avaliação. Tais aspectos foram percebidos nos relatos das coordenadoras, as quais sentem que muitos pais e professores não veem a necessidade de se envolverem em tal processo.

Acreditamos ser necessário que as escolas desenvolvam mecanismos de motivação e de conscientização da comunidade escolar, a fim de perceberem que a partir do momento em que a escola adotar o PPP como instrumento de trabalho, só terá a ganhar, pois se consolidará como uma instituição democrática, autônoma, e que acompanha os anseios e as mudanças da sociedade.

Em relação ao trabalho do coordenador pedagógico junto ao projeto político pedagógico, alguns aspectos também se destacam. As duas coordenadoras pesquisadas reconhecem a importância do PPP para a realização de seus trabalhos, afirmando ser esse documento a base do trabalho da escola e o principal meio de a mesma oferecer um bom desenvolvimento a seus alunos. No entanto, ao nos remetermos às suas práticas de trabalho com esse documento, pouca coisa foi-nos relatado.

A coordenadora A afirmou que iniciou nesse cargo há pouco tempo e, por isso, não possui uma prática de trabalho com o referido documento. Já a coordenadora B nos relatou que tenta trabalhar com o PPP, mas nem sempre consegue devido à falta de tempo, pois a demanda de trabalho na escola é grande, o que dificulta sua dedicação ao projeto político pedagógico.

Faz-se necessário refletirmos aqui sobre o PPP, pois, por meio do estudo teórico realizado para 
a concretização deste trabalho, constatamos ser primordial que o coordenador faça uso desse projeto em seu trabalho. Sendo o PPP o principal documento da escola, nele estão concentradas todas as intenções, limitações, anseios, planos, metas e objetivos da mesma. É imprescindível que esse documento não seja elaborado apenas por questões burocráticas, mas seja, de fato, colocado em prática pela comunidade escolar e gerido pelos sujeitos que a compõem.

Sendo o coordenador pedagógico o principal responsável pela efetivação do PPP, é imprescindível que ele também esteja em constante processo de formação. Ser coordenador pedagógico não significa estar em uma função à frente do professor, mas sim estar em uma função que detém características de dinamismo, responsabilidade e, principalmente, comprometimento com a escola e com a aprendizagem dos alunos. Sendo assim, ressaltamos haver necessidade de um olhar mais atento sobre os coordenadores pedagógicos, os quais, muitas vezes, também precisam ser ouvidos e atendidos. Cabe aos órgãos superiores, às escolas, prever meios de atendimento a esses profissionais, oferecendo-lhes melhores condições de trabalho. Acreditamos, também, que é preciso haver um maior comprometimento com o projeto político pedagógico, a fim de que esse documento leve em consideração a identidade da escola e de seus usuários.

\section{Referências}

ANDRÉ, M. O cotidiano escolar, um campo de estudo. In. PLACCO, V. M. N. de S.; ALMEIDA, L. R. de. (Orgs.). $O$ coordenador pedagógico e o cotidiano da escola. São Paulo, Loyola, 2003.

AMDRIOLLO, D. B. Desafios e Conquistas na construção da gestão compartilhada. In: Gestão em rede. Curitiba: CONSED, 2008.

BRASIL, Ministério da Educação. Lei de Diretrizes e Bases da Educação. Brasília, 2007.

CLEMENTI, N. A voz dos outros e a nossa voz. In: ALMEIDA, L. R. de; PLACCO, V. M. N. de S. O coordenador pedagógico e o espaço da mudança. 8 . ed. São Paulo: Loyola, 2010.

DIÓGENES, E. M. N.; CARNEIRO, M. J. M. C. A gestão participativa e o projeto político pedagógico: um exercício de autonomia. Revista Brasileira de política e Administração da Educação. ANPAE- Associação Nacional de política e Administração da Educação. Rio de Janeiro, 2005.
DUNY, A. As contradições do projeto coletivo: emancipação ou manipulação? In: Gestão em Rede. Curitiba: Consed, 2005. n. 89.

FILIPKOWSKI, M. L. Do percebido à ação supervisora: encaminhamentos para a formação continuada. In. RIBAS, M. H. Formação de professores: escola, práticas e saberes. Ponta Grossa: UEPG, 2005.

GARRIDO, E. Espaço de Formação Continuada para o professor-coordenador. In: BRUNO, E. B. G.; ALMEIDA, L. R. de; CHRISTV, L. H. (Orgs.). O coorde-nador pedagógico e a formação docente. 9. ed. São Paulo: Loyola, 2008.

GRINSPUN, M. P. S. Zipiin (Org.). A prática dos orientadores educacionais. 4. ed. São Paulo: Cortez, 2001.

LUDKE, M.; MARLI, E. D. A. Pesquisa em educação: abordagens qualitativas. São Paulo: EPU, 1986.

LÜCK, H. Ação integrada: administração, supervisão e orientação educacional. Petrópolis: Vozes, 1989.

MIZIERA, I. C. O coordenador pedagógico e o universo escolar. Disponível em: <www.psicopedagogia.com. br/opiniao>. Acesso em: 22/03/2010.

ORSOLON, L. A. M. O coordenador/formador como um dos agentes de transformação da/na escola. In: ALMEIDA, L. R. de; PLACCO, V. M. N. de S. O coordenador pedagógico e o espaço da mudança. 8 . ed. São Paulo: Loyola, 2010.

PIMENTA, S. G.: O pedagogo na escola pública. São Paulo: Loyola, 1991.

VASCONCELLOS, C. dos S. Coordenação do trabalho pedagógico: do projeto político-pedagógico ao cotidiano da escola. 5. ed. São Paulo: Libertad, 2004.

VEIGA, I. P. A. Perspectivas para reflexão em torno do projeto político-pedagógico. In: VEIGA, I. P. A.; RESENDE, L. M. G. de. (Orgs.). Escola: espaço do projeto político-pedagógico. Campinas: Papirus, 1998.

Enviado para Publicação: 20/06/2012 Aceito para publicação: $31 / 07 / 2012$ 
